\title{
Role of reactive oxygen species in bradykinin-induced proliferation of vascular smooth muscle cells
}

\author{
VICTORIA VELARDE ${ }^{1}$, PAULA M DE LA CERDA ${ }^{1}$, CLAUDIA DUARTE $^{1}$, \\ FRANCISCA ARANCIBIA ${ }^{1}$, EDUARDO ABBOTT ${ }^{1}$, ALEJANDRO GONZÁLEZ ${ }^{1}$, \\ FRANCESCA MORENO ${ }^{1}$ and AYAD A JAFFA ${ }^{2}$
}

\author{
${ }^{1}$ Facultad de Ciencias Biológicas, Pontificia Universidad Católica de Chile, Santiago, Chile \\ ${ }^{2}$ Medical University of South Carolina, Charleston, SC, USA
}

\begin{abstract}
In addition to the induction of cell proliferation and migration, bradykinin (BK) can increase c-fos mRNA expression, activate ERK $1 / 2$ and generate reactive oxygen species (ROS) in vascular smooth muscle cells (VSMC). It is not known, however, whether BK can induce cellular proliferation and extracellular matrix production via redox-sensitive signaling pathways. We investigated the role(s) of ROS in proliferation, migration and collagen synthesis induced by BK in VSMC derived from Sprague Dawley rat aorta. BK (10 $\mathrm{nM})$ increased VSMC proliferation by $30 \%(\mathrm{n}=5)$; this proliferation was inhibited by the antioxidants $\mathrm{N}$ acetylcysteine $(20 \mathrm{mM})$ and $\alpha$-lipoic acid (LA, $250 \mathrm{mM})$. In addition, BK induced an increase in cell migration and in collagen levels that were blocked by LA. ROS production induced by BK $(n=10)$ was significantly inhibited by bisindolylmaleimide $(4 \mu \mathrm{M})$ and by PD98059 $(40 \mu \mathrm{M})$. These results suggest that: 1$)$ ROS participate in the mechanism(s) used by bradykinin to induce cellular proliferation; 2) bradykinin induces ROS generation through a pathway that involves the kinases PKC and MEK; and 3) ROS participate in the pathways mediating cell migration and the production of collagen as a response to treatment with bradykinin. To our knowledge, this is the first report describing mechanisms to explain the participation of $\mathrm{ROS}$ in the cellular proliferation and extracellular matrix pathway regulated by BK.
\end{abstract}

Key terms: bradykinin, antioxidants, migration, signal transduction, reactive oxygen species

\section{INTRODUCTION}

Vascular smooth muscle cells (VSMC) in mature animals are highly specialized cells that have as one of their major functions the regulation of vascular tone via contraction (Owens, 1995). VSMC proliferation is normally quiescent in the adult, and mitogenic activity is rarely exhibited when cells contract during the hemodynamic regulation state. However, in disease where significant vascular injury occurs, such as diabetes and hypertension, VSMC growth is stimulated when the physiologic and regulatory balances between inhibitory and stimulatory signals are disrupted. These alterations in the signals for cell growth and matrix production can ultimately lead to atherosclerosis and its subsequent progression. Elucidation of the early cellular events accompanying the deregulation of VSMC growth and differentiation during the initiation and subsequent course of atherogenesis is of great importance in understanding the etiology of this disorder (Ross, 1993). Dysfunction of and/or damage to the endothelial cells lining the vasculature accompanied by reductions in the production of nitric oxide are also postulated to have a major role in increased VSMC proliferation (Bauer et al., 2001).

Several important cellular signaling mediators have been implicated in the dedifferentiation of the VSMC and its change from a contractile to a proliferative

Corresponding author: Victoria Velarde Ph.D., Laboratorio de Fisiología, Facultad de Ciencias Biológicas,

Pontificia Universidad Católica de Chile, Alameda 340, Casilla 114 D, Santiago, Chile. Telephone: (562) 686-2858,

Fax: (562) 222-5515. E-mail: mvelarde@bio.puc.cl 
phenotype. They include the vasoactive peptides (angiotensin II, endothelin-1, and bradykinin) and polypeptide growth factors (EGF, PDGF, IGF-1, FGF-2 and TGF- $\beta$ ) (Schwartz and Liaw, 1993). Recent evidence also suggests that many of these mediators can induce the production of reactive oxygen species (ROS). ROS production is significantly increased in injured vasculature and to a variety of experimental and clinical conditions, such as ischemia-reperfusion (Bertuglia and Giusti, 2003), thrombosis, diabetes (Giugliano et al., 1996), myocardial infarction (Ide et al., 2001) and angioplasty (Roller et al., 2001). In addition, in several types of models, experimental observations suggest that ROS are important in inducing cell proliferation, DNA synthesis and protooncogene mRNA expression (Baas and Berk, 1995). Reactive oxygen intermediates, such as superoxide anion $\left(\mathrm{O}_{2}{ }^{-}\right)$, hydrogen peroxide $\left(\mathrm{H}_{2} \mathrm{O}_{2}\right)$ and the hydroxyl radical (HO), are increasingly considered as a new family of second messenger molecules (Finkel, 1999).

The vasoactive peptide bradykinin (BK) is an important regulator of the normal physiologic function of the vasculature. Increasingly, however, pathophysiologic actions attributable to $\mathrm{BK}$ including phenotypical and structural changes of VSMC are also being recognized. It has been reported that $\mathrm{BK}$ induces VSMC proliferation (Yau et al., 2001), and we have previously observed that BK induces c-fos mRNA expression via pathways dependent on the generation of ROS and on ERK $1 / 2$ activation, a step in the signaling pathway considered prerequisites for cellular proliferation (Velarde et al., 1999). In addition, BK induced ERK 1/2 activation and c-fos mRNA expression are inhibited by antioxidants (Greene et al., 2000).

Previous reports in studies involving HaCaT keratinocytes (Coutant et al., 1997) and lymphocytes (McFadden and Vickers, 1989) also indicate that BK induces migration in a dose-dependent manner, suggesting an important role for $\mathrm{BK}$ in this event. $\mathrm{BK}$ also induces VSMC to synthesize extracellular matrix proteins. We have observed that $\mathrm{BK}$ increases TGF- $\beta$ mRNA and the mRNA for the $\alpha 2$-subunit of collagen (Douillet et al., 2000). Treatment of cells with BK also activates intracellular signaling mediators, such as NF-кB (Xie et al., 2000) and AP-1 (El-Dahr et al., 1996, 1998). However, the upstream or downstream signaling intermediates attributable to $\mathrm{BK}$ that activate $\mathrm{NF}-\kappa \mathrm{B}$ are currently not known. ERK 1/2 activation in response to $\mathrm{BK}$ stimulation occurs via a signaling cascade involving the $\mathrm{B} 2$ receptor, PKC, MEK and ultimately ERK 1/2 (Velarde et al., 1999). Although this pathway is mediated by ROS (Greene et al., 2000), the specific sequence of events resulting in the production of ROS and downstream effects affected by the pathway have not been previously identified. The purpose of the current set of studies is to investigate the specific role(s) of ROS in proliferation, migration and collagen synthesis induced by BK treatment in VSMC.

\section{METHODS}

\section{VSMC culture}

Aortic vascular smooth muscle cells obtained from 75-150 g male SpragueDawley rats (Rattus norvegicus) were prepared by a modification of the Majack method (Majack and Clowes, 1984). A two$\mathrm{cm}$ segment of aorta, cleaned of fat and adventitia, was incubated in $1 \mathrm{mg} / \mathrm{ml}$ collagenase for 3 hours at room temperature. The aorta was then cut into small sections and fixed to a culture flask for explantation in Minimal Essential Medium (MEM) (Gibco-BRL, Gaithersburg, MD, USA) supplemented with $10 \%$ fetal Calf Serum (FCS), 100 units/ml of penicillin and 100 $\mu \mathrm{g} / \mathrm{ml}$ of streptomycin, and incubated at $37^{\circ}$ $\mathrm{C}$ in a humidified atmosphere of $95 \%$ air and $5 \% \mathrm{CO}_{2}$. Cells were identified as vascular smooth muscle cells by their characteristic morphology and contractile properties, by their positive staining with an antibody against $\alpha$-actin, and their negative staining with an antibody against Von-Willebrand's factor. Cells were used between passages 2 and 6 in all experiments. Quiescence was induced by transferring the 60-70\% confluent cell cultures to MEM devoid of 
serum and growth factors for 48 hours prior to the treatments with various chemicals.

\section{$\left[{ }^{3} \mathrm{H}\right]$-Thymidine incorporation and DNA synthesis}

Rate of DNA synthesis in cultured rat VSMC was estimated by the rate of incorporation of $\left[{ }^{3} \mathrm{H}\right]$-thymidine into cellular DNA. Quiescent VSMC cultured in 6-well cell culture plates were treated with different agonists in serum-free medium for 24 hours and then pulsed labeled with $1 \mu \mathrm{Ci} / \mathrm{ml}$ of $\left[{ }^{3} \mathrm{H}\right]$-thymidine (DuPont NEN) for another 16 hours. Cells were then washed 3 times with PBS, precipitated with perchloric acid, washed with PBS and solubilized with 0.5 $\mathrm{ml}$ of SDS $0.1 \% / \mathrm{NaOH} 0.1 \mathrm{~N}$. Radioactivity was determined using a liquid scintillation counter (Watson et al., 2001).

\section{Cell migration assay}

VSMC migration was assessed using a modified Boyden chamber (Corning, Inc.). VSMC suspended in MEM were added to the upper chamber, and tested samples were added to the bottom chamber. After 4 hours of incubation at $37^{\circ} \mathrm{C}$, cells in the filter were fixed, the upper surface was scraped and the filter was stained with hematoxylin. The average number of cells from 4 randomly-chosen, high-power (400x) fields on the lower surface of the filter were counted (Miao et al., 2000).

\section{Collagen determination}

Quiescent VSMC in 6-well plates were treated with BK $(10 \mathrm{nM})$ for 48 hours in the presence of ascorbic acid $(50 \mu \mathrm{M})$. Twentyfour hours before the end of the incubation period, ${ }^{3} \mathrm{H}$-Proline was added to each well. Following the subsequent incubation, the medium was collected and separated into two fractions. One fraction was treated with collagenase $(20 \mathrm{U})$ for $90 \mathrm{~min}$ at $37^{\circ} \mathrm{C}$. Both fractions were concentrated using a speedvac, and proteins were subsequently resolved on a $5 \%$ polyacrylamide gel. Following electrophoresis, the gels were fixed in methanol/acetic acid for $60 \mathrm{~min}$ and incubated in increasing concentrations of acetic acid. Finally, the gels were incubated in a $20 \%$ 2,5-diphenyloxazole (PPO) solution in acetic acid for 2 hours, dried and exposed to an X-ray film for $48 / 72$ hours. Bands were scanned, and densitometric analysis was performed using the NIHImage program (Ichiki et al., 1997).

\section{Determination of $N F-\kappa B$ activation}

VSMC were harvested following treatment with $\mathrm{BK}$ for $30 \mathrm{~min}$ in the presence or absence of antioxidants. Nuclear extracts were prepared as described by Dignam et al. (1983). Briefly, cells were resuspended in $400 \mu \mathrm{l}$ of a hypotonic buffer $(10 \mathrm{mM}$ HEPES pH 7,9; $1.5 \mathrm{mM} \mathrm{MgCl}_{2} ; 10 \mathrm{mM}$ $\mathrm{KCl} ; 0.5 \mathrm{mM}$ DTT; $0.5 \mathrm{mM}$ PMSF; $0.5 \%$ Nonidet P-40) at $4^{\circ} \mathrm{C}$. Extracts were then centrifuged at $15,000 \mathrm{~g}$ for $1 \mathrm{~min}\left(\right.$ at $4^{\circ} \mathrm{C}$ ), and the supernatants collected. The nuclear pellets were resuspended in hypertonic buffer (10 mM HEPES pH 7.9; $1.5 \mathrm{mM}$ $\mathrm{MgCl}_{2} ; 420 \mathrm{mM} \mathrm{NaCl} ; 0.5 \mathrm{mM}$ DTT; 0.2 mM EDTA; 0,5 mM PMSF; $25 \%$ glycerol), centrifuged at $15,000 \mathrm{~g}$ for $10 \mathrm{~min}$ (at $4^{\circ} \mathrm{C}$ ), and the supernatants collected.

Double-stranded oligonucleotides were radio-labeled with $\gamma^{32} \mathrm{P}-\mathrm{ATP}$ and T4 kinase. Binding assays were performed with $5 \mu \mathrm{g}$ of protein extract, $1.5 \mu \mathrm{g}$ of poly[d(I-C) $], 5 \mu \mathrm{l}$ of buffer [50 mM HEPES (pH 7.8), 5mM spermidine, $15 \mathrm{mM} \mathrm{MgCl}$, $36 \%$ glycerol, $3 \mathrm{mg} / \mathrm{ml} \mathrm{BSA}, 0.3 \%$ Nonidet P-40, $15 \mathrm{mM}$ DTT], and 40,000 to $70,000 \mathrm{cpm}$ of ${ }^{32} \mathrm{P}-$ labeled oligo-nucleotide, with water added for a final volume of $25 \mu \mathrm{l}$. Reactions were incubated for $15 \mathrm{~min}$ on ice before addition of ${ }^{32} \mathrm{P}$-labeled oligonucleotide, then for an additional $15 \mathrm{~min}$ at room temperature. For competition with unlabeled oligonucleotide, a 100-fold molar excess of oligonucleotide relative to the radio-labeled probe was added to the binding assay. Samples were electrophoresed on $4 \%$ non-denaturing polyacrylamide gels, dried and autoradiographed (El-Dahr et al., 1996).

\section{Measurement of intracellular ROS generation}

VSMC were plated into 96-well plates and cultured as described above. When cells 
reached confluency, they were loaded with 10 $\mu \mathrm{M}$ of the $\mathrm{H}_{2} \mathrm{O}_{2}$-sensitive fluorescent probe 2'7'-dichlorofluorescein diacetate (DCF-DA; Molecular Probes) for 2 hours at $37^{\circ} \mathrm{C}$. Once inside the cell, non-fluorescent DCF-DA is deacetylated enzymatically by cellular esterases to 2'7'-dichlorofluorescein, which remains trapped within the cell. DCF fluoresces in the presence of intracellular peroxides. After loading, VSMC were washed with Earle's buffer and pre-incubated with the antagonists or inhibitors for the appropriate times, followed by treatment with $\mathrm{BK}$ or $\mathrm{H}_{2} \mathrm{O}_{2}$ as positive control. Readings were taken in a fluorometer using an excitation wavelength of 485 and an emission wavelength of 530, immediately after the stimulation and every 5 minutes for the following $30 \mathrm{~min}$ (Royall and Ischiropoulous, 1993).

\section{Statistical analysis}

Data are expressed as mean \pm SEM and were analyzed by the non-parametric methods of Kruskal-Wallis for multiple comparisons and the Mann-Whitney $U$ test for unpaired two sample analyses. Differences were considered significant at $\mathrm{p}<0.05$.

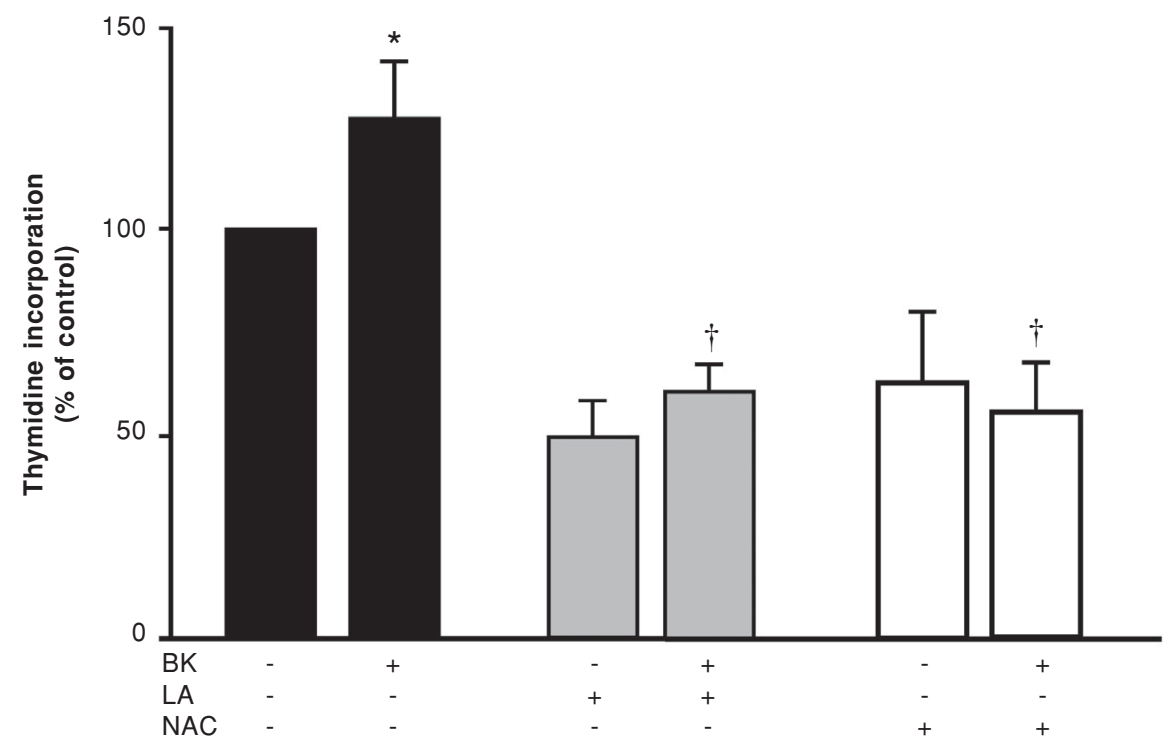

Figure 1. Basal and bradykinin-induced proliferation are inhibited by antioxidants. VSMC were pre-incubated with antioxidants Lipoic acid (LA, $250 \mu \mathrm{M})$ for 2 hours or with N-AcetylCysteine (NAC, $15 \mathrm{mM}$ ) for $45 \mathrm{~min}$ followed by a 24-hour incubation with BK 10nM. Bars represent average \pm standard error for 4 experiments. ${ }^{*}=\mathrm{p}<0.05$ compared to control. $\dagger=\mathrm{p}<0.05$ compared to BK.

\section{Participation of ROS in bradykinin-induced proliferation}

It has previously been reported that BK induces VSMC proliferation (Yang et al., 2003). To determine whether cell proliferation was mediated by the generation of ROS, VSMC were preincubated with the antioxidants $\alpha$-lipoic acid (LA, $250 \mu \mathrm{M}$ ) for 2 hours or $\mathrm{N}$ acetylcysteine (NAC, $15 \mathrm{mM}$ ) for 45 minutes followed by a 24-hour incubation with BK (10 nM). As shown in figure 1, $\mathrm{BK}$ induced a significant increase in cell proliferation $(133 \pm 10 \%)(\mathrm{n}=8, \mathrm{p}<0.05)$. Pre-incubation with either antioxidant alone decreased basal proliferation $(48 \pm 5$ $\%$ for $L A$ and $61 \pm 20 \%$ for NAC) $(n=4$, $\mathrm{p}<0.05)$. Proliferation induced by $B K$ in the presence of antioxidants was significantly inhibited compared to $\mathrm{BK}$ alone and was not significantly different from controls incubated with the antioxidants alone $(60 \pm 5 \%$ for $\mathrm{BK}+\mathrm{LA}$ and $54 \pm 13 \%$ for BK+NAC $)(n=4)$, suggesting that ROS are involved in bradykinin's proliferative effect. 
Participation of ROS on the activation of $N F \kappa-B$ by bradykinin

To determine whether ROS was mediating BK-induced NF- $\kappa \mathrm{B}$ activation in VSMC, we stimulated the cells for $30 \mathrm{~min}$ with increasing concentrations of $\mathrm{BK}\left(10^{-9}\right.$ to $10^{-7}$ $\mathrm{M})$ and observed a dose-dependent increase in NF- $\mathrm{KB}$ signaling in the nucleus (Fig 2A). To determine whether NF- $\mathrm{BB}$ activation is mediated by ROS production, cells were preincubated with LA for 2 hours or NAC for 45 min followed by treatment with BK $\left(10^{-8}\right.$ M) for $30 \mathrm{~min}$. Incubation with LA alone induced an increase in NF- $\mathrm{B}$ activity, and the activation of NF- $\kappa \mathrm{B}$ induced by $\mathrm{BK}$ was not modified by LA (data not shown). Incubation with NAC alone did not modify the activation of NF- $\mathrm{KB}$ when compared to control, but significantly blocked BKinduced NF-KB activation (Fig 2B).
ROS production induced by bradykinin is dependent on the activation of PKC and $M E K$

To identify the potential position in VSMC BK signaling pathway(s) where ROS are generated, we used a pharmacological approximation using inhibitors of two kinases (PKC and MEK) known to be activated in response to BK. BK induces a significant increase in ROS production after $10 \min (159 \pm 19 \%, \mathrm{n}=5$, $\mathrm{p}<0.05)$. This increase is significantly inhibited by pre-incubation with bisindolylmaleimide (Bim, $4 \mu \mathrm{M})$, a broad-spectrum inhibitor of $\mathrm{PKC}$, and by the MEK inhibitor PD98059 $(40 \mu \mathrm{M})$ (Fig. 3 ). Incubation of the cells with Bim or PD98059 alone did not modify ROS production.
A
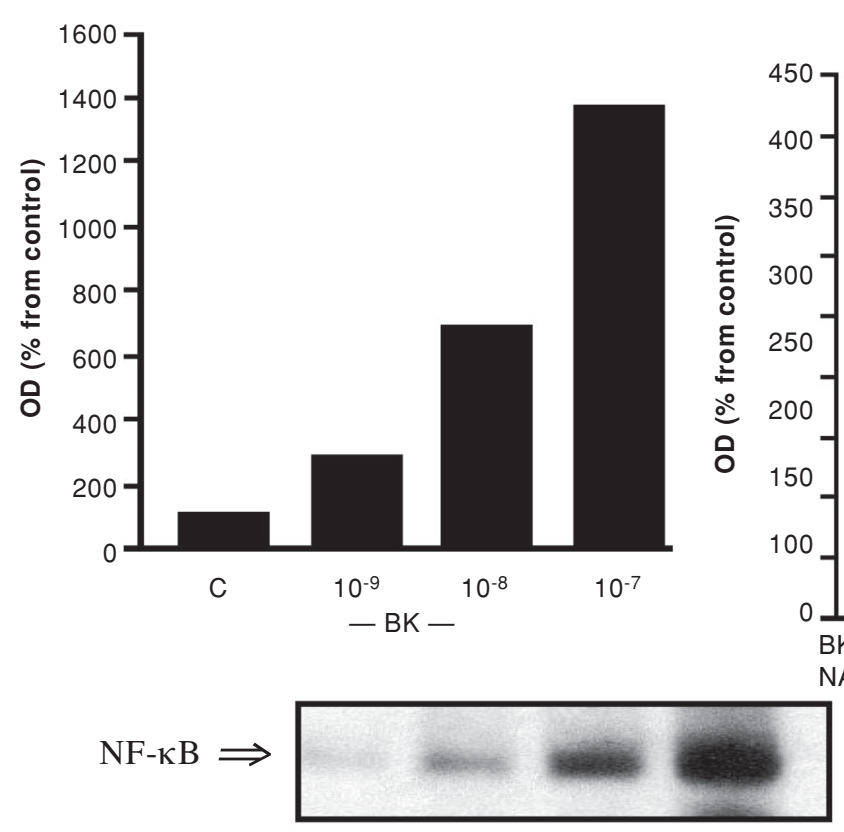

B

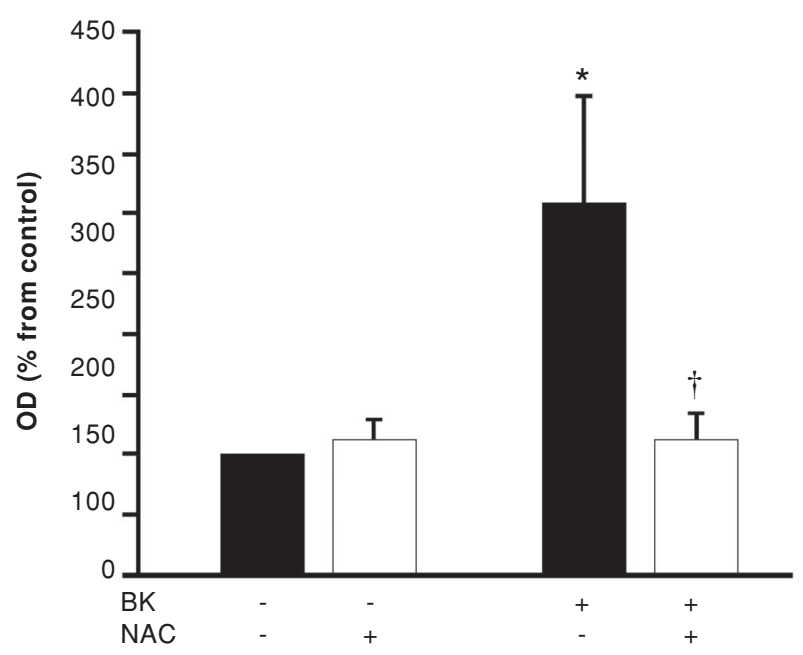

Figure 2. Effect of NAC on the activation of NF-kB induced by bradykinin. VSMC were stimulated with BK for $30 \mathrm{~min}$. A) dose response in NF- $\mathrm{BB}$ activation. B) Pre-incubation with NAC $(20 \mathrm{mM})$ for $45 \mathrm{~min}$. Bars represent average \pm standard error for 4 experiments. ${ }^{*}=\mathrm{p}<0.05$ compared to control. $\dagger=\mathrm{p}<0.05$ compared to BK. 


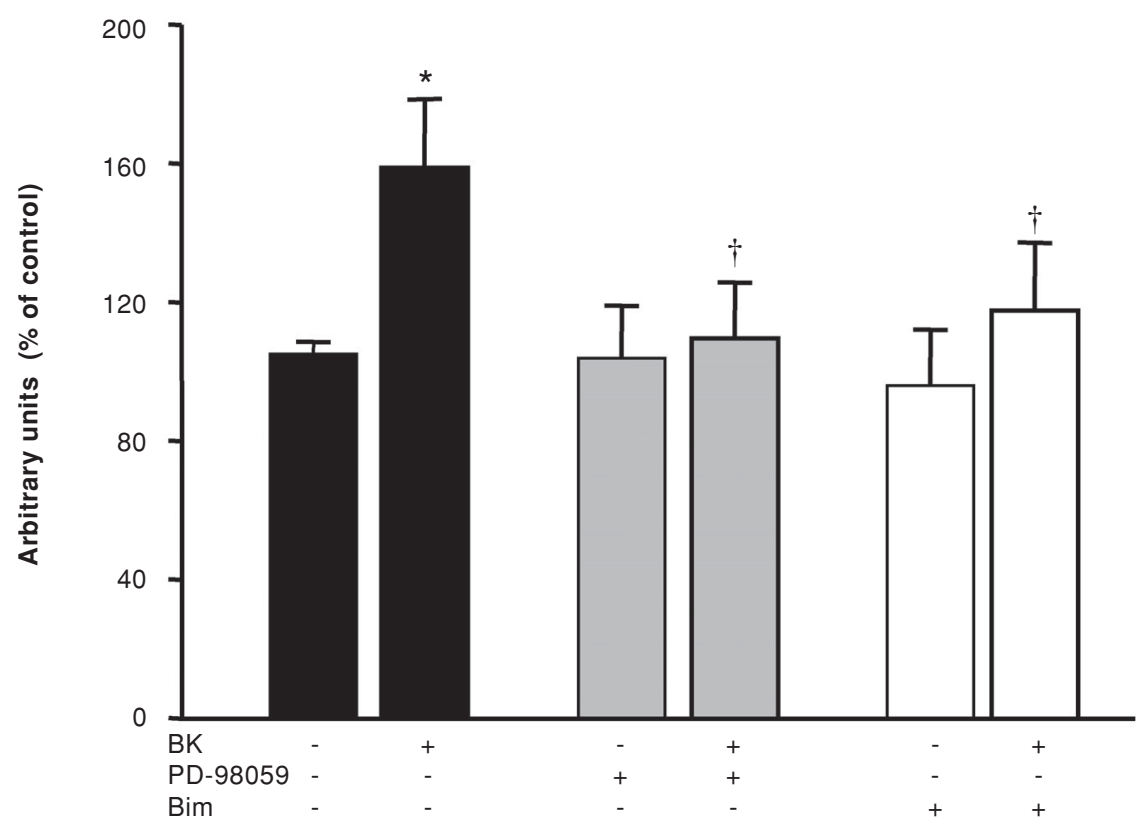

Figure 3. ROS production induced by bradykinin is dependent on PKC and MEK activities. VSMC were loaded with DCF for 1 hour and pre-incubated with PD98059 $(40 \mu \mathrm{M})$ or bisindolylmaleimide $(\mathrm{Bim}, 4 \mu \mathrm{M})$ for 30 minutes followed by the stimulation with $\mathrm{BK}$ for $10 \mathrm{~min}$. Bars represent average \pm standard error for 8 experiments. ${ }^{*}=\mathrm{p}<0.05$ compared to its own control in the absence of BK.

\section{Migration induced by bradykinin is mediated by ROS}

To determine whether $\mathrm{BK}$ was able to induce cell migration in VSMC, cells were incubated for 2 and 4 hours with BK. PDGF-BB was used as a positive control (Arita et al., 2002). At two hours, BK did not induce cell migration, whereas PDGF induced a marked increase in cell migration. However after 4 hours, BK induced a significant increase in cell migration when compared to control cells. The increase in migration was similar to that observed for PDGF (Fig 4A). To determine if the increase in migration was mediated by changes in ROS, cells were preincubated with the antioxidant LA for $2 \mathrm{~h}$ and stimulated with BK for 4 hours. Preincubation with LA did not change migration pattern in control cells but blocked migration induced by BK $(\mathrm{p}<0.05)$ and also reduced the cellular migration induced by PDGF (Fig 4B).
Collagen production induced by bradykinin is mediated by ROS

To determine the effects of $\mathrm{BK}$ on the production of extracellular matrix, we measured the production of collagen and also determined whether BK-induced alterations in collagen are affected by the production of ROS. For this purpose, VSMC were incubated with BK for 48 hours in the presence of ${ }^{3} \mathrm{H}$ Proline and ascorbic acid to induce collagen secretion. Secreted collagen was identified among the proteins that incorporated proline, based on a higher level of ${ }^{3} \mathrm{H}$-Proline incorporation, molecular weight and sensitivity to collagenase digestion (Ichiki et al., 1997). As expected, BK induced an increase in the quantity of ${ }^{3} \mathrm{H}$-Proline incorporated into collagen protein secreted from VSMC. Collagen secretion was not affected by preincubation with LA alone. However, BKinduced secretion of collagen was blocked when cells were treated with $\mathrm{BK}$ in the presence of LA (Fig 5). These results suggest that ROS participate in the signaling pathway that results in collagen synthesis and secretion. 
A

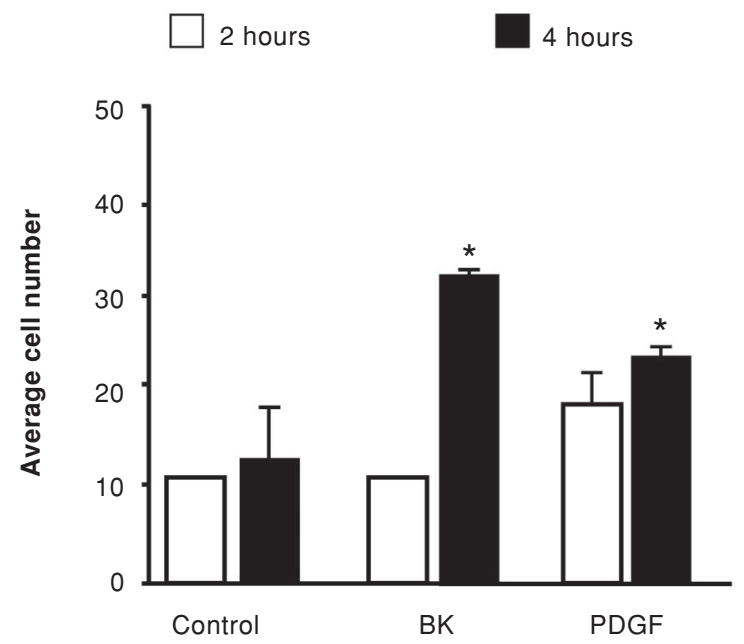

B

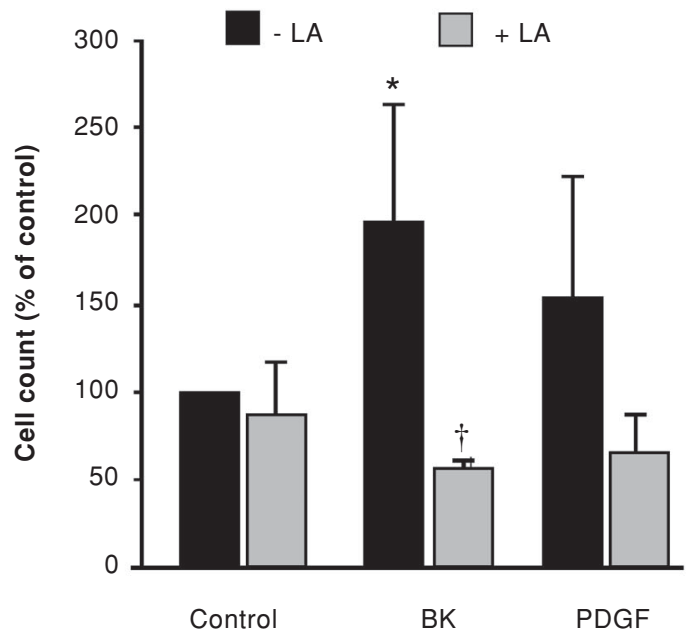

Figure 4. Lipoic acid inhibits cell migration induced by BK. A) VSMC were incubated with BK $(10 \mathrm{nM})$ or PDGF-BB $(1 \mathrm{nM})$ for 2 or 4 hours. B) VSMC were preincubated with lipoic acid (250 $\mu \mathrm{M})$ for 2 hours, followed by the incubation with BK(10nM) or PDGF-BB (1 nM) for 4h. Bars represent average \pm standard error for 4 experiments. ${ }^{*}=\mathrm{p}<0.05$ compared to control. $\dagger=\mathrm{p}<0.05$ compared to BK.

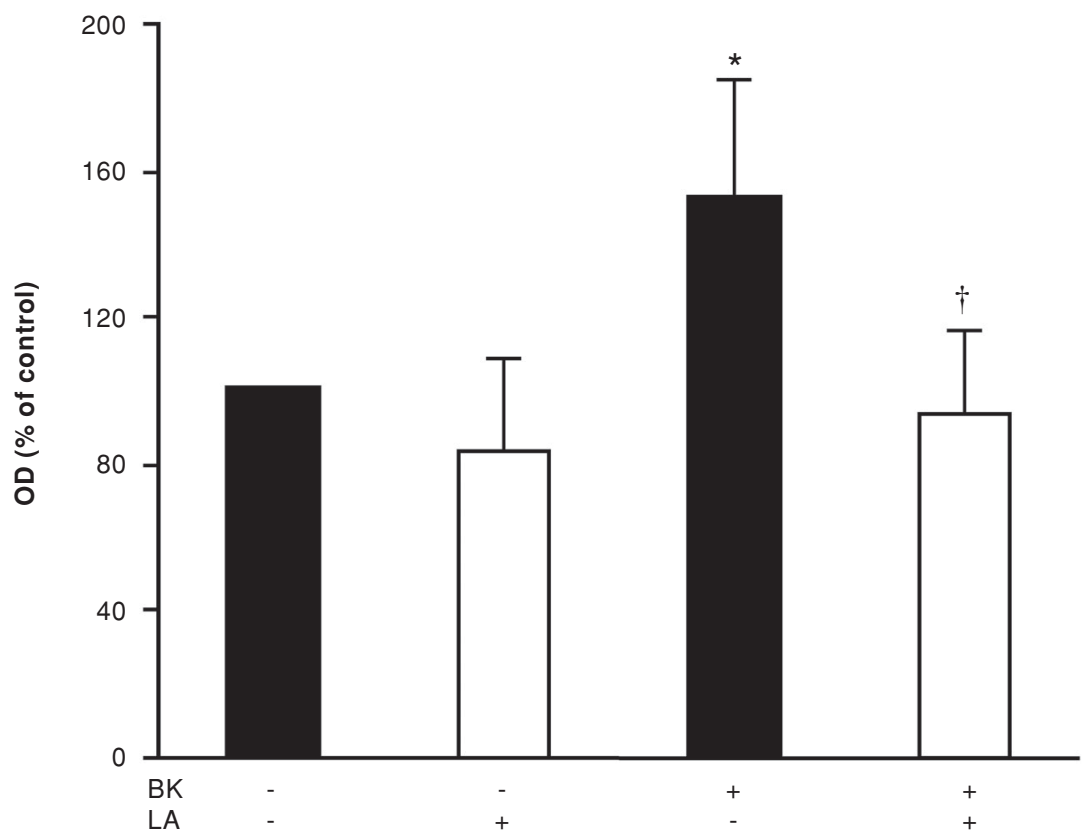

Figure 5. Bradykinin-induced collagen production is inhibited by lipoic acid. Cells were preincubated with lipoic acid $(250 \mu \mathrm{M})$ for 2 hours followed by the incubation with BK for 48 hours. Proline was added to the medium 24 hours before the end of the incubation. Bars represent average \pm standard error for 4 experiments. $*=p<0.05$ compared to control. $\dagger=p<0.05$ compared to BK. 


\section{DISCUSSION}

In the present work we have observed that: 1) ROS participate in the mechanism(s) used by bradykinin to induce cellular proliferation; 2) bradykinin induces ROS generation through a pathway that involves PKC and MEK; and 3) ROS participate in the pathways mediating cell migration and the production of collagen as a response to treatment with bradykinin.

Bradykinin is a potent polypeptide hormone released by the activation of the intrinsic pathway of coagulation. Once released, $B K$ activates $B_{2}$ receptors expressed on the surface of endothelial cells, which leads to the activation of ERK 1/2 (Leiva-Salcedo et al., 2002) and also to the liberation of $\mathrm{NO}$ and prostaglandin $\mathrm{I}_{2}$ to the space between the endothelium and the smooth muscle cell layer (Ruschitzka et al., 1999), producing an endothelium-dependent relaxation. However, in several pathologic situations including diabetes and hypertension and following procedures like angioplasty, which are associated with vascular injury, the endothelium may become dysfunctional. In the presence of a dysfunctional and/or absent endothelium, circulating vasoactive peptides can interact directly with the VSMC layer. We, and others, have observed that BK can induce proliferation of VSMC in vitro (Yau et al., 2001), and we have postulated that BK can be considered among the factors involved in the phenotypic dedifferentiation of vascular cells and the development of atherosclerosis. In addition, many of the pathophysiologic disease process affecting the vasculature are known to be associated with increases in oxidative stress. In this investigation, we have postulated that several of the effects on VSMC that are induced by BK, such as proliferation, migration and synthesis of matrix proteins, are mediated by the generation of ROS.

The induction of proliferation by bradykinin has been a controversial topic. Several groups have observed an increase in proliferation in different cell types (Higashida et al., 1996; El-Dahr et al., 1998), while others have observed the opposite effect (Alric et al., 1999; Dixon et al., 1997). Our results in VSMC have shown a modest but significant effect of BK on the induction of proliferation, similar to what has been observed for angiotensin II (Makita et al., 1995), another vasoactive peptide postulated to induce proliferation in VSMC. This is in contrast to the effects observed by others in VSMC from mesenteric artery (Dixon et al., 1997). The differing results between the two studies could be due to differences in the origin of the smooth muscle cells (ours came from the aorta, while theirs come from the mesenteric artery) and the treatment given to the cells (FBS was absent in our cells; they stimulated theirs in the presence of fetal serum). This modest but significant effect of $\mathrm{BK}$ on cell proliferation is consistent with the notion that $\mathrm{BK}$ and angiotensin II are not competence factors as are PDGF or FGF, but rather progression factors.

Pre-incubation with the antioxidants LA and NAC without any other stimulus produces a decrease in cell proliferation when compared to control, suggesting that ROS partly mediate the basal proliferation rate of VSMC in primary culture. This effect could be explained considering that the preparation of primary cultures is possibly a stress stimulus that could induce mild changes in the phenotype of VSMC. Despite the presence of a basal proliferation rate, our results indicate that $\mathrm{BK}$ induces a significant additional increase in proliferation that was inhibitable by antioxidants. These results suggest the participation of ROS in the signaling pathway leading to cellular proliferation induced by BK. ROS are known to be involved in both proliferative and antiproliferative events depending on the concentration generated, site of production, whether they are secreted or remain within the cell, the cellular type that is generating them, and the presence of an anti-oxidant defense system. In macrophages, the production of ROS is abundant and not only stays within the cell but is secreted to the extracellular compartment as well; these conditions favor cell death (Forman and Torres, 2001). On the other hand, in vascular cells the production of ROS is 
limited to the intracellular compartment and in smaller concentrations, favoring a proliferative state ( $\mathrm{Li}$ and Shah, 2003). Potential sources of ROS in VSMC have been suggested, and a major source recently identified in these cells is the enzyme $\mathrm{NAD}(\mathrm{P}) \mathrm{H}$ oxidase. It is possible that this enzyme complex is responsible for generating the ROS production that we observed in our current studies. In a previous set of studies where we used diphenylene-iodonium (DPI), a potent NAD $(\mathrm{P}) \mathrm{H}$ oxidase inhibitor, we blocked ROS production and ERK 1/2 activation induced by BK (Greene et al., 2000).

Extensive evidence indicates that ROS regulate gene expression by modulating a large number of transcription factors, including the nuclear transcription factor kappa $\mathrm{B}(\mathrm{NF}-\kappa \mathrm{B})$. It has been observed that $\mathrm{H}_{2} \mathrm{O}_{2}$ is capable of activating NF- $\kappa \mathrm{B}$ in some cell types. In addition, in human aortic smooth muscle cells IL-1 $\beta$ induces the activation of $\mathrm{NF}-\kappa \mathrm{B}$ via the production of ROS (Hoare et al., 1999). Several authors have proposed that BK can induce NF- $\kappa \mathrm{B}$ activation (Xie et al., 2000) but most of these studies have been done in cell lines. Based on this evidence, we studied the effect of $\mathrm{BK}$ on $\mathrm{NF}-\kappa \mathrm{B}$ activation in VSMC. As was expected, BK induced an increase in $N F-\kappa B$ that was concentrationdependent, and in agreement with the evidence in literature, we proposed that ROS could be mediating this effect. Unexpectedly, LA did not reduce BKinduced increase in nuclear $\mathrm{NF}-\kappa \mathrm{B}$. To confirm this result, we used another antioxidant (DPI) with similar results (data not shown). To our surprise, the preincubation with a third antioxidant, NAC, inhibited $\mathrm{BK}$-induced $\mathrm{NF}-\kappa \mathrm{B}$ activation. At present, we have no clear explanation for these results but propose two potential explanations. First, in tissues LA can be converted into its reduced form, dihydrolipoic acid, and as such, can act as a pro-oxidant (Packer et al., 1995). On the other hand, it has been postulated that NAC acts through a pathway independent of scavenging ROS (Zafarullah et al., 2003). NAC raises intracellular GSH levels and thereby provides GSH peroxidase with the co-substrate to eliminate ROS (Zhang et al., 1991).

In order to determine some key intracellular signaling intermediates that require activation for the generation of ROS, we used a pharmacologic approach of two important kinases (PKC and MEK). The PKC inhibitor Bim inhibited BK stimulation of ROS, suggesting that this enzyme is required for BK-induced generation of ROS. When MEK was inhibited by PD98059, we also observed an inhibition of the response induced by BK. We did not expect this result, since we previously have observed that antioxidants blocked p42/44 MAPK activation, suggesting that ROS were generated before the activation of MEK. One way to explain our results is to consider the existence of two separate but not inconsistent scenarios for how ROS are involved in ERK signaling. First, it is possible that PKC activation is important for the generation of ROS via NADPH oxidase. An additional mechanism to explain how PD-98059 might reduce ROS production is the existence of a second instance where ROS are produced, which is dependent on ERK activation (Seshiah et al., 2002). Future experiments in which the time frame of the experimental protocol is manipulated will be required to address this issue.

Migration of medial smooth muscle cells into the intima is an important process in various vascular proliferative diseases. Although the mechanisms responsible for this migration are not fully understood, several factors produced in response to vascular injury have been implicated in this process. BK has long been considered as an inflammatory factor, which has an important effect on neutrophil migration (Paegelow et al., 2002). In addition, BK can induce the migration of keratinocytes (Coutant et al., 1997) but not of endothelial cells from post-capillary venules in culture (Morbidelli et al., 1998). We have observed that BK can induce VSMC migration in a similar magnitude to the one observed for PDGF, a classical chemotactic agent for medial VSMC (Liu et al, 1989). There is abundant evidence suggesting the participation of ROS on cell migration. In 
fact, $\mathrm{H}_{2} \mathrm{O}_{2}$ induces cell migration in bovine aortic endothelial cells (Yasuda et al., 1999). In addition, arachidonic acid (AA) induces migration through a pathway that involves the production of ROS (Nishio and Watanabe, 1997). Our results indicate that ROS mediate the migration induced by BK, although we have not yet determined whether this effect is mediated by AA production. However, it has been shown that BK is capable of mobilizing AA in VSMC (Zhang et al., 1991).

In addition to proliferation and migration, the remodeling of the extracellular matrix is an important feature of atherosclerosis and other diseases. In myocardial infarction, it has been observed that angiotensin converting enzyme (ACE) inhibitors reduce hypertrophy and fibrosis. This antifibrotic effect is in part mediated by an increase in the concentration of $\mathrm{BK}$ (Gallagher et al., 1998). However, this inhibition seems to be mediated by the generation of NO and prostacyclin from the endothelium (Farhy et al., 1993). In addition, ACE inhibitors have not been effective in all studies (the Mercator Study Group, 1992); this evidence suggests that the beneficial effect of $\mathrm{BK}$ on the myocardium depends on a functional endothelial layer. In previous experiments, we observed an increase in collagen mRNA in response to BK in VSMC (Douillet et al., 2000). Our current results show that the protein for collagen is also increased and that this effect is likely to be mediated via a pathway involving ROS. This observation has also been reported in a set of studies suggesting that angiotensin II uses a similar pathway to generate increased collagen production in cardiomyocytes (Sorescu and Griendling, 2002). Although we have used ascorbic acid in the incubation medium as a cofactor to increase collagen secretion (Davidson et al., 1997), its effect as an antioxidant is not relevant because of the low concentrations used (De Tullio and Arrigoni, 2004).

In summary, our results suggest that, under conditions in which BK is present at high concentrations, such as inflammation and diabetes, and in the absence of a functional endothelial surface layer, BK participates in the induction of cell proliferation, migration and increase in extracellular matrix production through a mechanism that involves the generation of ROS. To our knowledge, this is the first report implicating ROS in the proliferative and migratory pathways of bradykinin.

\section{ACKNOWLEDGEMENTS}

This study was supported by Grants FONDECYT \#1000660 and DIPUC\#2754005 (Dr. Victoria Velarde). We thank Dr. Samir El-Dahr, Dr. Eddie Greene, Dr. Rocio Foncea and Dr. Mauricio Boric for their helpful discussion and assistance, and Giuliana Marchetti for technical assistance.

\section{REFERENCES}

ALRIC C, PECHER C, BASCANDS JL, GIROLAMI JP (1999) Effect of bradykinin on tyrosine kinase and phospha-tase activities and cell proliferation in mesangial cells. Immunopharmacol 45: 57-62

ARITA Y, KIHARA S, OUCHI N, MAEDA K, KURIYAMA H, OKAMOTO Y, KUMADA M, HOTTA K, NISHIDA $M$, TAKAHASHI M, NAKAMURA T, SHIMOMURA I, MURAGUCHI M, OHMOTO Y, FUNAHASHI T, MATSUZAWA Y (2002) Adipocyte-derived plasma protein adiponectin acts as a platelet-derived growth factor-BB-binding protein and regulates growth factor-induced common postreceptor signal in vascular smooth muscle cell. Circulation 105: 2893-2898

BAAS AS, BERK BC (1995) Differential activation of mitogen activated protein kinase by $\mathrm{H}_{2} \mathrm{O}_{2}$ and $\mathrm{O}_{2}^{-}$in vascular smooth muscle cells. Circ Res 77: 29-36

BAUER PM, BUGA GM, IGNARRO LJ (2001) Role of $\mathrm{p} 42 / \mathrm{p} 44$ mitogen-activated-protein and $\mathrm{p} 21^{\text {waf/cip } 1}$ in the regulation of vascular smooth muscle cell proliferation by nitric oxide. Proc Natl Acad Sci USA 98: 12802-12807

BERTUGLIA S, GIUSTI A (2003) Microvascular oxygenation, oxidative stress, NO suppression and superoxide dismutase during postischemic reperfusion. Am J Physiol 285: H1064-H1071

COUTANT KD, CORVAIA N, RYDER NS (1997) Bradykinin induces actin reorganization and enhances cell motility in $\mathrm{HaCaT}$ keratinocytes. Biochem Biophys Res Commun 237: 257-261

DAVIDSON JM, LUVALLE PA, ZOIA O, QUAGLINO D, GIRO, MG (1997) Ascorbate differentially regulates elastin and collagen biosynthesis in vascular smooth muscle cells and skin fibroblasts by pretranslational mechanisms. J Biol Chem 272: 345-352

DE TULLIO MC, ARRIGONI O (2004) Hopes, disillusions and more hopes from vitamin C. Cell Mol Life Sci 61: 209-219

DIGNAM JD, MARTIN PL, SHASTRY BS, ROEDER RG (1983) Eukaryotic gene transcription with purified components. Methods Enzymol 101: 582-98 
DIXON BS, DENNIS M (1997) Regulation of mitogenesis by kinins in arterial smooth muscle cells. Am J Physiol 273: C7-C20

DOUILLET CD, VELARDE V, CHRISTOPHER JT, MAYFIELD RK, TROJANOWSKA ME, JAFFA AA (2000) Mechanisms by which bradykinin promotes fibrosis in vascular smooth muscle cells: Role of TGFbeta and MAPK. Am J Physiol 279: H2829-H2837

EL-DAHR SS, DIPP S, YOSIPIV IV, BARICOS WH (1996) Bradykinin stimulates c-fos expression, AP1 DNA binding activity and proliferation of rat glomerular mesangial cells. Kidney Int 50: 1850-1855

EL-DAHR SS, DIPP S, BARICOS WH (1998) Bradykinin stimulates the ERK $\rightarrow$ Elk-1 $\rightarrow$ Fos/AP-1 pathway in mesangial cells. Am J Physiol 275: F343-F352

FARHY RD, CARRETERO OA, HO KL, SCICLI AG (1993) Role of kinins and nitric oxide in the effects of angiotensin converting enzyme inhibitors on neointima formation. Circ Res 72: 1202-1210

FINKEL T (1999) Signal transduction by reactive oxygen species in non-phagocytic cells. J Leukoc Biol 65: 337340

FORMAN HJ, TORRES M (2001) Redox signaling in macrophages. Mol Aspects Med 22: 189-216

GALLAGHER AM, YU H, PRINTZ MP (1998) Bradykinininduced reductions in collagen gene expression involve prostacyclin. Hypertension 32: 84-88

GIUGLIANO D, CERIELLO A, PAOLISSO G (1996) Oxidative stress and diabetic vascular complications. Diabetes Care 19: 257-267

GREENE EL, VELARDE V, JAFFA AA (2000) Role of reactive oxygen species in bradykinin-induced mitogen-activated protein kinase and c-fos induction in vascular cells. Hypertension 35: 942-947

HIGASHIDA H, HASHII M, YOKOYAMA S, TAKETO M, HOSHI N, NODA M, ZHONG ZG, SHAHIDULLAH M, MINABE Y, NAKASHIMA S, NOZAWA Y (1996) Bradykinin B2 receptor and signal transduction analyzed in NG 108-15 neuroblastoma $\mathrm{x}$ glioma hybrid cells, B2 receptor transformed NIH/3T3 fibroblasts. Prog Brain Res 113: 215-230

HOARE GS, MARCZIN N, CHESTER AH, YACOUB MH (1999) Role of oxidant stress in cytokine-induced activation of NF-kappaB in human aortic smooth muscle cells. Am J Physiol 277: H1975-H1984

ICHIKI Y, SMITH EA, LEROY EC, TROJANOWSKA M (1997) Basic fibroblast growth factor inhibits basal and transforming growth factor-beta induced collagen alpha 2(I) gene expression in scleroderma and normal fibroblast. J Rheumatol 24: 90-95

IDE $\mathrm{T}$, TSUTSUI $\mathrm{H}$, HAYASHIDANI $\mathrm{S}$, KANG D, SUEMATSU N, NAKAMURA K, UTSUMI H, HAMASAKI N, TAKESHITA A (2001) Mitochondrial DNA damage and dysfunction associated with oxidative stress in failing hearts after myocardial infarction. Circ Res 88: 529-535

LEIVA-SALCEDO E, PÉREZ V, ACUÑA-CASTILLO C, WALTERS R, SIERRA F (2002) T-kininogen inhibits kinin-mediated activation of ERK in endothelial cells. Biol Res 35: 287-294

LI JM, SHAH AM (2003) ROS generation by nonphagocytic NADPH oxidase: Potential relevance in diabetic nephropathy. J Am Soc Nephrol 14: S221-S226

LIU MW, ROUBIN GS, KING SB (1989) Restenosis after coronary angioplasty. Circulation 79: 1374-1387

MAJACK RA, CLOWES AW (1984) Inhibition of vascular smooth muscle cell migration by heparin-like glucosaminoglycans. J Cell Physiol 118: 253-256

MAKITA S, NAKAMURA M, YOSHIDA H, HIRAMORI K (1995) Effect of angiotensin II receptor blocker on angiotensin II stimulated DNA synthesis of cultured human aortic smooth muscle cells. Life Sci 56: 383388

MCFADDEN RG, VICKERS KE (1989) Bradykinin augments the in vitro migration of nonsensitized lymphocytes. Clin Invest Med 12: 247-253

MERCATOR STUDY GROUP (1992) Does the new angiotensin converting enzyme inhibitor cilazapril prevent restenosis after percutaneous transluminal coronary angioplasty? Results of the MERCATOR study: A multicenter, randomized, double-blind placebo-controlled trial. Multicenter European Research Trial with Cilazapril after Angioplasty to Prevent Transluminal Coronary Obstruction and Restenosis (MERCATOR) Study Group. Circulation 86: $100-110$

MIAO RQ, MURAKAMI H, SONG Q, CHAO L, CHAO J (2000). Kallistatin stimulates vascular smooth muscle cell proliferation and migration in vitro and in neointima formation in balloon injured rat arteries. Circ Res 86: 418-424

MORBIDELLI L, PARENTI A, GIOVANNELLI L, GRANGER HJ, LEDDA F, ZICHER M (1998) B1 receptor involvement in the effect of bradykinin on venular endothelial cell proliferation and potentiation of FGF-2 effects. Br J Pharmacol 124: 1286-1292

NISHIO E, WATANABE Y (1997) The regulation of mitogenesis and apoptosis in response to the persistent stimulation of alpha1-adrenoceptors: A possible role of 15-lipoxygenase. Br J Pharmacol122: 1516-1522

OWENS GK (1995) Regulation of differentiation of vascular smooth muscle cells. PhysiolRev 75: 487-517

PAEGELOW I, TRZECZAK S, BOCKMANN S, VIETINGHOFF G (2002) Migratory responses of polymorphonuclear leukocytes to kinin peptides. Pharmacology 66: 153-161

PACKER L, WITT EH, TRITSCHLER HJ (1995) Alphalipoic acid as a biological antioxidant. Free Rad Biol Med 19: 227-250

ROLLER RE, NIMMRICHTER V, TRINKER M, SEINOST G, SCHNEDL WJ, PILGER E (2001) Oxidative stress during peripheral angioplasty. Implication for late restenosis? Int Angiol 20: 131-135

ROSS R (1993) The pathogenesis of atherosclerosis: A perspective for the 1990s. Nature 362: 801-809

ROYALL JA, ISCHIROPOULOUS H (199) Evaluation of 2'7'-dichlorofluorescin and dihydro-rhodamine 123 as fluorescent probes for intracellular $\mathrm{H}_{2} \mathrm{O}_{2}$ in cultured endothelial cells. Arch Biochem Biophys 302: 348-355

RUSCHITZKA F, CORTI R, NOLL G, LUSCHER TF (1999) A rationale for treatment of endothelial dysfunction in hypertension. J Hypertension 17: S25S35

SCHWARTZ SM, LIAW L (1993) Growth control and morphogenesis in the development and pathology of arteries. J Cardiovasc Pharmacol 21: S31-S49

SESHIAH PN, WEBER DS, ROCIC P, VALPPU L, TANIYAMA Y, GRIENDLING KK (2002) Angiotensin II stimulation of $\mathrm{NAD}(\mathrm{P}) \mathrm{H}$ oxidase activity: Upstream mediators. Circ Res 91: 406-413

SORESCU D, GRIENDLING KK (2002) Reactive oxygen species, mitochondria, and $\mathrm{NAD}(\mathrm{P}) \mathrm{H}$ oxidases in the development and progression of heart failure. Congest Heart Fail 8: 132-140

VELARDE V, ULLIAN ME, MORINELLI TA, MAYFIELD RK, JAFFA AA (1999) Mechanisms of MAPK activation by bradykinin in vascular smooth muscle cells. Am J Physiol 277: C253-C261

WATSON PA, NESTEROVA A, BURANT CF, KLEMM DJ, REUSCH JEB (2001) Diabetes-related changes in 
cAMP response element-binding protein content enhance smooth muscle cell proliferation and migration. J Biol Chem 276: 46142-46150

XIE P, BROWNING DD, HAY N, MACKMAN N, YE RD (2000) Activation of NF-kappaB by bradykinin through a Galpha(q)- and Gbeta gamma-dependent pathway that involves phosphoinositide 3-kinase and Akt. J Biol Chem 275: 24907-24914

YANG CM, CHIEN CS, MA YH, HSIAO LD, LIN CH, WU C (2003) Bradykinin B2 receptor-mediated proliferation via activation of the Ras/Raf/MEK/MAPK pathway in rat vascular smooth muscle cells. J Biomed Sci 10: 208-18

YASUDA M, OHZEKI Y, SHIMIZU S, NAITO S, OHTSURU A, YAMAMOTO T, KUROIWA Y (1999)
Stimulation of in vitro angiogenesis by hydrogen peroxide and the relation with ETS-1 in endothelial cells. Life Sci 64: 249-258

YAU L, WILSON DP, WERNER JP, ZAHRADKA P (2001) Bradykinin receptor antagonists attenuate neointimal proliferation postangioplasty. Am J Physiol 281: H1648-H1656

ZAFARULLAH M, LI WQ, SYLVESTER J, AHMAD M (2003) Molecular mechanisms of $\mathrm{N}$-acetylcysteine actions. Cell Molec Life Sci 60: 6-20

ZHANG H, GAGINELLA TS, CHEN X, CORNWELL DG (1991) Action of bradykinin at the cyclooxygenase step in prostanoid synthesis through the arachidonic acid cascade. Agents and Actions 34: 397-404 